\title{
Parasitisation by Bathycreadium elongatum (Digenea, Opecoelidae) in pyloric caeca of Trachyrincus scabrus (Teleostei, Macrouridae)
}

\author{
M. Constenla ${ }^{1, *}$, M. Carrassónn ${ }^{1}$, C. M. Moyà ${ }^{1}$, A. Fernàndez-Chacón ${ }^{1}$, F. Padrós ${ }^{1}$, \\ A. Repullés-Albelda ${ }^{1,2}$, F. E. Montero ${ }^{1,2}$ \\ ${ }^{1}$ Departament de Biologia Animal, Biologia Vegetal i Ecologia, Universitat Autònoma de Barcelona, Cerdanyola, \\ 08193 Barcelona, Spain \\ ${ }^{2}$ Cavanilles Institute of Biodiversity and Evolutionary Biology and Department of Zoology, University of Valencia, \\ 46100 Valencia, Spain
}

\begin{abstract}
A novel process of transmural passive displacement of a digenean parasite was studied in the digestive tract of the roughsnout grenadier Trachyrincus scabrus, which is found in the northwestern Mediterranean Sea. This mechanism seems to facilitate the elimination of a significant portion of intestinal parasites. The digenean parasite Bathycreadium elongatum was found in the intestine, mainly within pyloric caeca, in $74.4 \%$ of $T$. scabrus, with a mean abundance of 44 individuals per fish. Nodule-like lesions were also found in the mesentery of pyloric caeca of infected T. scabrus. Histological sections of the nodules revealed granulomatous inflammatory responses surrounding degraded digeneans. Partial nucleotide sequences of the 28S rRNA gene obtained from intracaecal $B$. elongatum and from the core of the nodules of the mesentery of pyloric caeca showed $100 \%$ mutual identity with an overlap of $971 \mathrm{bp}$. The greatest abundance of both intracaecal $B$. elongatum and nodules occurred in spring. During summer, and especially autumn, the abundance of intracaecal B. elongatum decreased. Prevalence and abundance of nodules increased in autumn. In winter intracaecal parasite abundance and prevalence began to increase, but decreased again in nodules. During spring and summer, parasites pass into the visceral cavity, hypothetically owing to the fragility of the wall of pyloric caeca in their apical zone, and become degraded through a granulomatous inflammatory response. This process seems to have a detrimental effect on the $B$. elongatum cycle since some of parasites are trapped and degrade in the connective tissue in which they are unable to complete their life cycle.
\end{abstract}

KEY WORDS: Trachyrincus scabrus - Bathycreadium elongatum - Foreign body · Nodules · Pyloric caeca Resale or republication not permitted without written consent of the publisher

\section{INTRODUCTION}

Host-parasite interactions have received considerable attention as biological models for adaptation, but in the case of metazoan parasites in fish, there are a limited number of studies available, of which very few are for deep-sea ecosystems (Bray 2004, Klimpel et al. 2006, Palm \& Klimpel 2008).
In aquatic ecosystems, digeneans are widely distributed and diverse and as fish parasites they have succeeded in colonising fishes from shallow waters to the deep sea. Very few digenean species can be considered to be strict deep-sea parasites; most species that do reach into abyssal depths have a wide bathymetric distribution (Bray 2004). The habitat of most adult digenean parasites in fish is almost exclusively 
restricted to the digestive tract, either free in the paramucosal lumen or attached to digestive tissues (Dezfuli et al. 1997, Paperna \& Dzikowski 2006).

The digeneans of the family Opecoelidae are intestinal parasites described in a large range of fish species (Bray 1995, Cribb 2005). This family is one of the most frequently described in deep-sea species. It can be found in fishes from surface waters to more than $5000 \mathrm{~m}$ deep (Klimpel et al. 2009), and this depth range is mainly determined by the habitat of its intermediate and definitive hosts (Bray 2004). Gadiform fishes are dominant in the deep sea and many species within this order are definitive hosts for opecoelids (Klimpel et al. 2001, Bray 2004). Species of Bathycreadium are opecoelid digeneans that parasitise deep-sea gadiform fishes, such as Phycis phycis (Jousson et al. 1999), in the North Atlantic Ocean and the Mediterranean Sea (Klimpel et al. 2001).

Trematodes are not considered to cause diseases in the digestive tract of fish, and if they do the pathology is very weak (Erasmus 1972, Paperna \& Dzikowski 2006). However, a few cases of adult digeneans causing pathology in fish are described including penetration into the mucosa of the digestive tract, as in the cases of the 2 hemiurids Stomachicola muraenesocis in the stomach (Nasira et al. 1998) and Lecithocladium invasor in the oesophagus (Chambers et al. 2001). These hemiurids induce a granulomatous inflammatory response within the host tissue.

In a preliminary study on the roughsnout grenadier Trachyrincus scabrus (Rafinesque, 1810) (Gadiformes, Macrouridae) from the deep-sea waters in the western Mediterranean Sea we found a high prevalence of Bathycreadium elongatum (Maillard 1970) (syn. Nicolla elongata) located within pyloric caeca. Unexpectedly, B. elongatum was also found in the mesentery outside of the pyloric caeca of T. scabrus, together with several extracaecal nodules (henceforth called nodules). As $B$. elongatum is considered to be a strict parasite of the digestive tract, this particular location was considered an interesting finding and worthy of more detailed investigations.

The aims of this study are to (1) characterise the main macroscopic and histological alterations in Trachyrincus scabrus associated with the digenean Bathycreadium elongatum; (2) explore the content of nodules by morphological and molecular studies;
(3) estimate the prevalence, abundance and maturity of intracaecal B. elongatum and of nodules throughout the year; and (4) attempt to explain the abnormal location for an intestinal parasite such as B. elongatum in the mesentery of pyloric caeca.

\section{MATERIALS AND METHODS}

Specimens of Trachyrincus scabrus $(\mathrm{n}=120)$ were captured in 2007 from the continental slope offshore of the Barcelona coast in Spain (River Besòs mouth, NW Mediterranean) at depths of between 500 and $1025 \mathrm{~m}$ (Table 1). Samples were collected by the RV 'García del Cid' (OTSB) and by a commercial fishing boat (BOU), in the framework of the MEC Spanish oceanographic project BIOMARE (CTM2006-13508C02-01/MAR). Fish samples were obtained seasonally (Table 1). Total length (TL) of each fish was measured to the nearest millimetre on board (Table 1), and 3 categories of size classes were assigned (Size 1: $\mathrm{TL}<25 \mathrm{~cm}$; Size 2: $\mathrm{TL}=25-30 \mathrm{~cm}$; Size 3: TL $>30 \mathrm{~cm}$ ). Fish were preserved immediately after capture: 80 specimens were frozen at $-20^{\circ} \mathrm{C}$ until dissection, and 40 were fixed in $10 \%$ buffered formalin with the abdominal cavity opened to facilitate penetration of the preservative.

In the spring of 2009, 15 additional specimens of Trachyrincus scabrus were captured by a commercial fishing boat at about $560 \mathrm{~m}$ depth (Table 1). Five of these fish were immediately dissected to provide adequate material for molecular and morphological

Table 1. Trachyrincus scabrus. Mean \pm SD sampling depth $(\mathrm{m})$, mean $\pm \mathrm{SD}$ total length $(\mathrm{cm})$ and size classes $(\mathrm{cm})$ used for the present study. TL: total length; $\mathrm{n}$ : number of specimens

\begin{tabular}{|lcccc|}
\hline Season & Depth & Size class & TL & $\mathrm{n}$ \\
\hline $\mathbf{2 0 0 7}$ & & & & \\
Winter & $720 \pm 90.51$ & $\mathrm{TL} \leq 25$ & $19.0 \pm 0.00$ & 2 \\
& & $25<\mathrm{TL} \leq 30$ & $27.97 \pm 0.90$ & 19 \\
& & $30<\mathrm{TL}$ & $32.4 \pm 2.40$ & 9 \\
Spring & $609.5 \pm 72.12$ & $\mathrm{TL} \leq 25$ & $22.36 \pm 1.62$ & 17 \\
& & $25<\mathrm{TL} \leq 30$ & $27.9 \pm 2.97$ & 5 \\
& & $30<\mathrm{TL}$ & $35.13 \pm 5.17$ & 8 \\
Summer & $759.92 \pm 177.03$ & $\mathrm{TL} \leq 25$ & $23.0 \pm 1.30$ & 10 \\
& & $25<\mathrm{TL} \leq 30$ & $26.0 \pm 0.00$ & 4 \\
Autumn & $843.83 \pm 161.37$ & $30<\mathrm{TL}$ & $33.35 \pm 2.61$ & 16 \\
& & $\mathrm{TL} \leq 25$ & $23.5 \pm 2.12$ & 5 \\
2009 & & $25<\mathrm{TL} \leq 30$ & $27.75 \pm 1.77$ & 15 \\
Spring & $560 \pm 60.05$ & $30<\mathrm{TL}$ & $36.84 \pm 4.67$ & 10 \\
& & $\mathrm{TL} \leq 25$ & $22.18 \pm 1.19$ & 11 \\
& & $25<\mathrm{TL} \leq 30$ & $27.0 \pm 0.00$ & 4 \\
\hline
\end{tabular}


studies, and the other 10 fish were used to test whether the presence of nodules was recurrent throughout the years.

The frozen fish were thawed, dissected and examined for the presence of metazoan parasites in the digestive tract under the stereomicroscope. All intracaecal specimens of Bathycreadium elongatum were counted and preserved in $70 \%$ ethanol. Nodules were detected and quantified. Four different categories were assigned according to the number of nodules found: none, 0 nodules; mild, 1-10 nodules; medium, 11-20 nodules; high, > 20 nodules. Of the total number of parasites from each season, $10 \%$ were examined to determine their stage of maturity. Digeneans were stained in iron acetic carmine, dehydrated through a graded ethanol series, cleared in dimethyl phthalate and mounted in Canada balsam. Maturity of the parasites was determined based on the size of the body and the degree of development of the gonads: (1) just recruited metacercariae, encapsulated small worms with no visible gonads or with small dark gonads; (2) juveniles, small worms with no visible gonads or with small dark gonads and scarce vitelline follicles; (3) adults, large worms with large and clear compact gonads, and well-developed vitelline fields; and (4) elderly individuals, large worms with senescent gonads (with a dark core surrounded by a clear halo within the gonad capsule) and developed vitelline fields. B. elongatum identification was performed based on specific taxonomic bibliography (Maillard 1970, Bray 1973, Cribb 2005) and on body size, extension of vitelline follicles, size and shape of oral and ventral suckers and egg size.

Samples of the digestive tract of the fish preserved in $10 \%$ buffered formalin were dissected and processed by routine paraffin histology techniques. Sections $(4 \mu \mathrm{m})$ were stained with haematoxylin and eosin (H\&E).

Genomic DNA was extracted from 2 adult gravid worms, 2 nodules and 2 metacercariae from freshly examined fish fixed in $100 \%$ ethanol by using the DNeasy $^{\mathrm{TM}}$ blood and tissue kit (Qiagen), following the manufacturer's protocol. Partial 28S rDNA sequences were amplified with the primers LSU5f (5'-TAG GTC GAC CCG CTG AAY TTA AGC A-3') and ECD2r (5'CTT GGT CCG TGT TTC AAG ACG GG-3') (Littlewood et al. 2000) for both Bathycreadium elongatum adults and nodules. Primers were combined with the internal primer 1200r (5'-GCA TAG TTC ACC ATC TTT CGG-3') (Littlewood et al. 2000). PCR was carried out in a $30 \mu \mathrm{l}$ reaction volume containing $1.5 \mathrm{U}$ of Thermoprime Plus DNA polymerase and $10 \times$ buffer with $1.5 \mathrm{mM} \mathrm{MgCl}_{2}$ (ABgene), $0.2 \mathrm{mM}$ of each de- oxyribonucleotide triphosphate (dNTP) and 15 pmol of each primer. Reactions were run on a Veriti ${ }^{\mathrm{TM}}$ 96-well thermal cycler (Applied Biosystems). Thermal cycling was initiated by denaturation (heating for 2 min at $95^{\circ} \mathrm{C}$ ), followed by 35 cycles of amplification (each comprising $95^{\circ} \mathrm{C}$ for $50 \mathrm{~s}$, annealing temperature at $52^{\circ} \mathrm{C}$ for $50 \mathrm{~s}$ and extension at $72^{\circ} \mathrm{C}$ for $50 \mathrm{~s}$ ) and terminated by elongation at $72^{\circ} \mathrm{C}$ for $7 \mathrm{~min}$. ITS 2 rDNA sequences were amplified by means of a set of primers ITS 3S (5'-GGT ACC GGT GGA TCA CGT GGC TAG TG-3') (Bowles et al. 1993) and ITS 2.2 (5'CCT GGT TAG TTT CTT TTC CTC CGC-3') (Cribb et al. 1998) for the DNA extracted from nodules and metacercariae. Thermal cycling was processed as described above with an annealing temperature at $51^{\circ} \mathrm{C}$. The amplified products were purified by using the Minielute PCR purification kit (Qiagen) and cycle-sequenced from both strands by using ABI BigDye ${ }^{\mathrm{TM}}$ Terminator v. 3.1 Ready Reaction Cycle sequencing kit, alcohol-precipitated and run on an ABI 3130xl automated sequencer. Contiguous sequences were assembled and edited with the Vector NTI Advance v. 10.3.0 software (Invitrogen) and submitted to GenBank under Accession Numbers JN085948 (adult $B$. elongatum 28S rDNA, 995 bp), JN089756 (nodule 28S rDNA, 971 bp), JN089758 (nodule ITS 2 rRNA, 412 bp) and JN089757 (metacercaria ITS 2 rRNA, 372 bp).

Prevalence (P) and mean abundance (A) of Bathycreadium elongatum (PB, $\mathrm{AB})$ and nodules (PN, $\mathrm{AN})$ were calculated according to Bush et al. (1997). PB, $\mathrm{AB}, \mathrm{PN}$ and $\mathrm{AN}$ were grouped by season, host size and sampling year (spring 2007 and spring 2009) and were statistically compared; significances of the differences between $\mathrm{PB}, \mathrm{PN}$ and $\mathrm{AN}$ were calculated with chi-squared $\left(\chi^{2}\right)$ tests. Variations of AB were determined with ANOVA and Student's $t$-test for year groups after verifying a normal distribution (Kolmogorov-Smirnoff test). When data did not fit the assumptions of normality and homogeneity of variances for ANOVA (AB), they were normalised by logarithmic transformation. The mean values of the transformed data were then compared by ANOVA followed by a Student-Newman-Keuls (SNK) multiple- comparison test. To test for interactions in $\mathrm{AB}$ and $\mathrm{AN}$ among seasonality and host size, 2-factor ANOVA was used. ANOVA was also used for a comparison of AB among the 4 categories of nodules.

\section{RESULTS}

Most of the fish sampled in 2007 (71.25\%) were found to be parasitised by Bathycreadium elongatum 
within the digestive tract (intestine and pyloric caeca), with an overall mean abundance of 33.53 parasites per fish. The main site location was the pyloric caeca ( $\mathrm{P}=62.50 \%$ [confidence limits, $\mathrm{CL}: 52-73 \%$ ] and $\mathrm{A}=15.16$ [CL: 9.27-21.05]). B. elongatum was occasionally found in co-infections with other digeneans, nematodes and/or acanthocephalans. Some metacercariae were found within the stomach of 3 specimens of Trachyrincus scabrus (Figs. 1 to 3). Specimens of Bathycreadium elongatum were found not only within the pyloric caeca of fish (Fig. 4), but some of them were also occasionally detected free in an extra-pyloric location within or close to the mesentery (Fig. 5).

During the gross examination, the apical zone of the pyloric caeca of Trachyrincus scabrus was found to be fragile and friable. In histological sections, a very thin wall at the tips of the pyloric caeca was observed in some cases. Some tips of pyloric caeca presented loss of continuity in a large number of specimens, in which intestinal mucus content came out through the opening to the visceral cavity (Fig. 6). Moreover, adjacent to the pyloric caeca tips, a signif- icant number of nodules (0.1 to $1.5 \mathrm{~mm})$ were detected in $68.75 \%$ of all specimens. Some of these nodules clearly contained digenean specimens. Histological sections of these nodules revealed a granulomatous inflammatory response, composed in most cases of a homogeneous necrotic core surrounded by an inflammatory cellular response, with macrophages being the most abundant cell type, and multilayered connective tissue which formed an extended surrounding layer (Figs. 7 \& 8). Occasionally, macrophage aggregates were closely associated with these nodules. Furthermore, in some cases digeneans in different stages of degradation could be identified within these nodules, as some structures (gonads, vitellarium, suckers, remnants of shell and yolk from eggs) could be detected (Figs. 8 \& 9).

Nucleotide sequences of the 28S rRNA gene region obtained from intracaecal Bathycreadium elongatum and from nodules of pyloric caeca showed 100\% mutual identity with an overlap of $971 \mathrm{bp}$. Nucleotide sequences of ITS 2 rDNA gene region obtained from the nodules and from isolated metacercariae also showed $100 \%$ mutual identity between them (over-
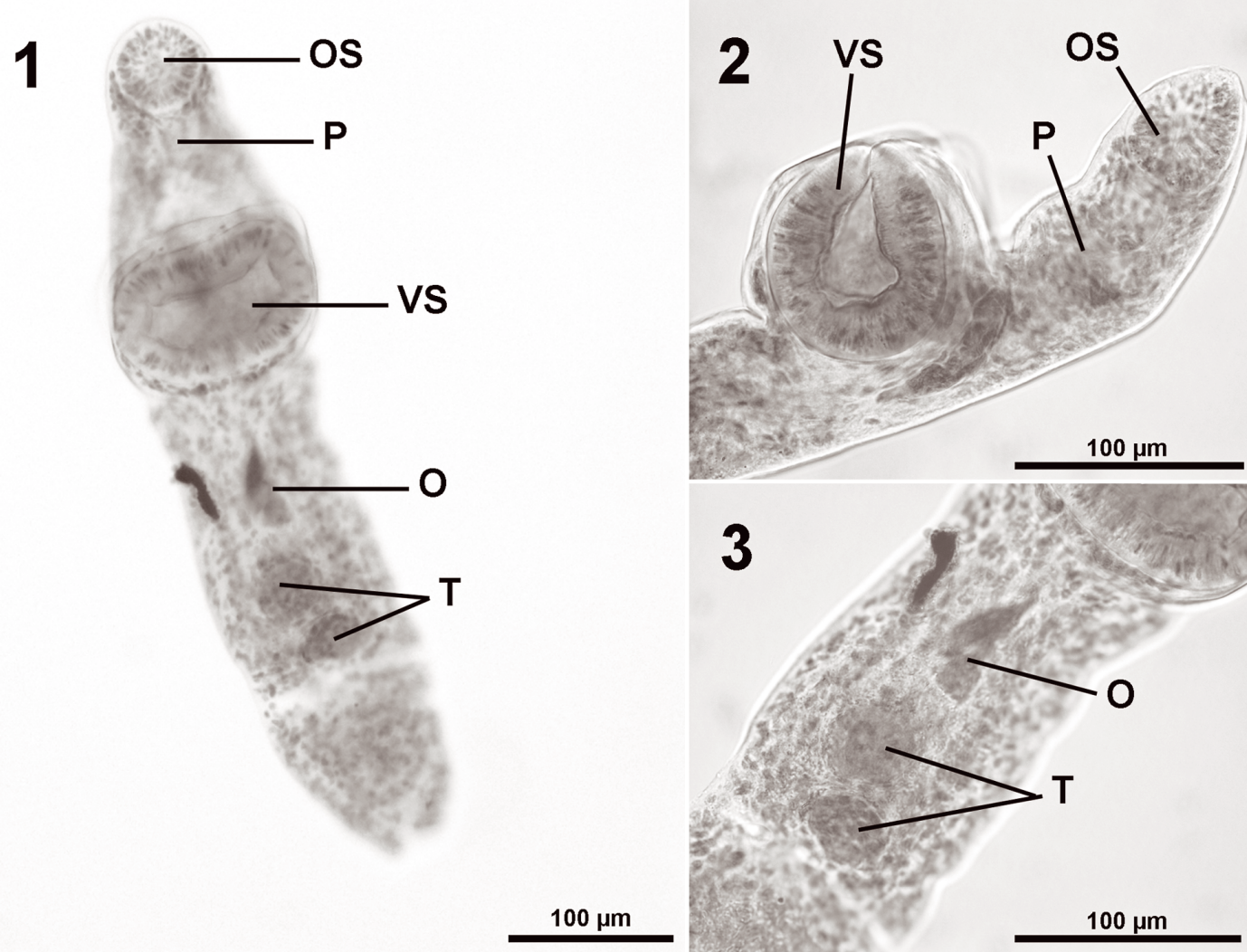

Figs. 1 to 3. Bathycreadium elongatum metacercaria. Fig. 1. Whole worm in ventral view. Fig. 2. Detail of the oral sucker and

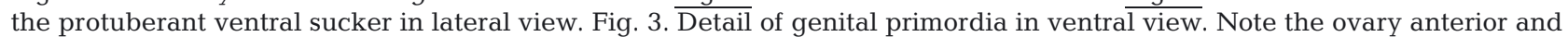
adjacent to the foremost testis in the median line (O: ovary; OS: oral sucker; P: pharynx; T: testis; VS: ventral sucker) 


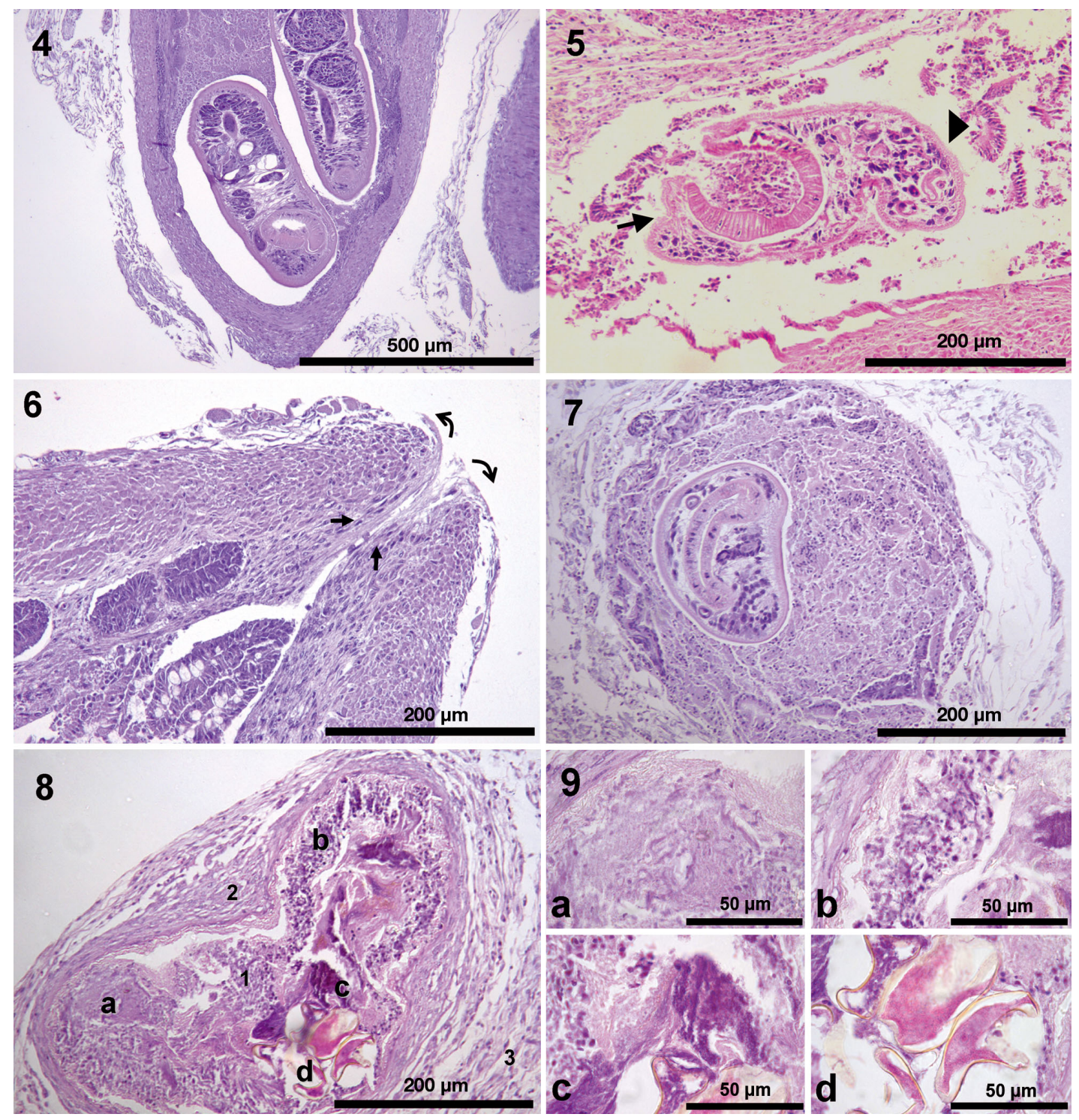

Figs. 4 to 9. Trachyrincus scabrus. Histological sections of pyloric caeca and nodules within the surrounding connective tissue. Fig. 4. Two digeneans within pyloric caeca. Fig. 5. Bathycreadium elongatum (arrow) surrounded by connective tissue and intestinal mucosa (arrowhead) outside the pyloric caeca. Fig. 6. Pyloric caeca losing their continuity and intestinal content (arrows) extruded into the visceral cavity through the opening. Fig. 7. Recent extruded material from pyloric caeca. Note the digenea and intestinal mucosa in different states of degradation surrounded by mesenteric tissue. Fig. 8. Nodule in connective tissue showing different layers: (1) degraded digenean, with remains of oral sucker (a), vitellaria (b), ovary (d), and (2) fibroblasts and macrophages; (3) mesenteric connective tissue. Fig. 9. Higher magnification of the digenean structures within the nodule shown in Fig. 8: (a) degraded oral sucker; (b) vitellaria; (c) ovary; (d) eggs

lap of $372 \mathrm{bp}$ ) and with the Genbank published sequence of Nicolla elongata (syn. B. elongatum).

In spring and summer, free Bathycreadium elongatum, sometimes associated with fragments of intestinal mucosa, were observed in the mesentery (Fig. 5). In these seasons, the prevalence of nodules with traces of parasite yolk and eggs was about 40 and $41 \%$, respectively. In autumn the nodule cores were quite degenerated and almost indistinguishable, but in winter the prevalence with traces of yolk was again almost $50 \%$.

Although intracaecal Bathycreadium elongatum were observed all year round, prevalence and abundance showed important fluctuations throughout the year 2007 (Table 2). The highest PB was registered in spring and was significantly different to those of winter $\left(\chi^{2}=12.907, p=0.000\right)$ and autumn $\left(\chi^{2}=10.989\right.$, $\mathrm{p}=0.001)$. Summer PB was also high and showed a 
Table 2. Bathycreadium elongatum. Mean (95\% CI) prevalence and abundance of the digenean (PB, AB) and nodules (PN, AN): comparisons (respective $\chi^{2}$ and ANOVA) among seasons. Mean values within a column accompanied by same superscript letters indicate lack of significant differences

\begin{tabular}{|c|c|c|c|c|c|}
\hline Season & $\mathrm{n}$ & PB (\%) & $\mathrm{AB}$ & $\mathrm{PN}(\%)$ & $\mathrm{AB}$ \\
\hline Spring & 20 & $\begin{array}{c}90^{\mathrm{a}} \\
(0.75-1.04)\end{array}$ & $\begin{array}{c}33.5^{\mathrm{a}} \\
(17.17-49.83)\end{array}$ & $\begin{array}{c}95^{\mathrm{a}} \\
(0.85-1.05)\end{array}$ & $\begin{array}{c}23.5^{\mathrm{a}} \\
(19.70-27.30)\end{array}$ \\
\hline Summer & 20 & $\begin{array}{c}80^{\mathrm{a}} \\
(0.60-0.99)\end{array}$ & $\begin{array}{c}13.25^{\mathrm{b}} \\
(3.38-23.12)\end{array}$ & $\begin{array}{c}50^{\mathrm{b}} \\
(0.26-0.74)\end{array}$ & $\begin{array}{c}11^{\mathrm{b}} \\
(5.33-16.66)\end{array}$ \\
\hline Autumn & 20 & $\begin{array}{c}40^{\mathrm{b}} \\
(0.16-0.64)\end{array}$ & $\begin{array}{c}2.10^{\mathrm{c}} \\
(0.24-3.96)\end{array}$ & $\begin{array}{c}75^{\mathrm{abc}} \\
(0.54-0.96)\end{array}$ & $\begin{array}{c}15.5^{\mathrm{c}} \\
(10.14-20.86)\end{array}$ \\
\hline Winter & 20 & $\begin{array}{c}35^{\mathrm{b}} \\
(0.12-0.58)\end{array}$ & $\begin{array}{c}10.90^{\mathrm{bc}} \\
(0.00-22.80\end{array}$ & $\begin{array}{c}55^{\mathrm{bc}} \\
(0.31-0.79)\end{array}$ & $\begin{array}{c}11.5^{\mathrm{bc}} \\
(5.76-17.24)\end{array}$ \\
\hline
\end{tabular}

Table 3. Bathycreadium elongatum. Mean (95\% CI) prevalence and abundance of the digenean (PB, AB) and nodules (PN, $\mathrm{AN}$ ): comparisons (respective $\chi^{2}$ and Student's $t$-test) between years. Mean values within a column accompanied by same superscript letters indicate lack of significant differences

\begin{tabular}{|lccccc|}
\hline Year & $\mathrm{n}$ & $\mathrm{PB}(\%)$ & $\mathrm{AB}$ & $\mathrm{PN}(\%)$ & $\mathrm{AN}$ \\
\hline Spring 2007 & 20 & $90^{\mathrm{a}}$ & $33.5^{\mathrm{a}}$ & $95^{\mathrm{a}}$ & $23.50^{\mathrm{a}}$ \\
& & $(0.76-1.04)$ & $(17.17-49.82)$ & $(0.85-1.05)$ & $(19.70-27.30)$ \\
Spring 2009 & 10 & $100^{\mathrm{a}}$ & $23.30^{\mathrm{a}}$ & $80^{\mathrm{a}}$ & $21.00^{\mathrm{a}}$ \\
& & & $(6.56-40.04)$ & $(0.50-1.10)$ & $(11.80-30.20)$ \\
\hline
\end{tabular}

significant decrease until the end of the year (summer to autumn, $\chi^{2}=6.667, \mathrm{p}=0.010$; summer to winter, $\left.\chi^{2}=8.286, p=0.004\right)$. Highest $A B$ was also found in spring (Table 2) and was significantly different from the rest of the seasons. Significant differences were also found in $\mathrm{AB}$ between summer and autumn $\left(F_{3.79}=10.654, \mathrm{p}=0.000\right)$. Specimens of B. elongatum were found in the pyloric caeca of fish collected in the spring of 2009, in which the $\mathrm{PB}$ was higher $(\mathrm{PB}=$ $100 \%)$ and $A B$ was lower $(A B=23.3)$ than those of the 2007 spring samples (Table 3), but trends were not significant. Differences in the developmental stage of the parasite were also observed throughout the year. Parasites observed during the winter and spring were predominantly juveniles ( $\mathrm{P}=85$ to $90 \%$ ), while in autumn, adult and senescent parasites were the phases mainly observed $(\mathrm{P}=75 \%)$. In spring, 5 metacercariae of $B$. elongatum were found within the stomach and intestine, and in winter 1 metacercaria was also found within the pyloric caeca. The prevalence of juveniles and adults was almost the same in summer ( $\mathrm{P}=55$ and $45 \%$, respectively). Prevalence and abundance of $B$. elongatum were significantly higher in the smaller Trachyrincus scabrus than in larger fish $\left(\chi^{2}=14.565, \mathrm{p}=0.001\right.$ and $F_{2.89}=5.148, \mathrm{p}=$ 0.008 , respectively) (Table 4 ).

Differences in prevalence and abundance of nodules throughout the year were also observed (Table 2). Spring was the season when the highest PN and AN were recorded, and significant differences were

Table 4. Bathycreadium elongatum. Mean (95\% CI) prevalence and abundance of the digenean (PB, AB) and nodules (PN, AN): comparisons (respective $\chi^{2}$ and ANOVA) among host sizes. Mean values within a column accompanied by same superscript letters lack of significant differences

\begin{tabular}{|c|c|c|c|c|c|}
\hline Size class $(\mathrm{cm})$ & $\mathrm{n}$ & PB (\%) & $\mathrm{AB}$ & PN (\%) & AN \\
\hline $\mathrm{TL} \leq 25$ & 30 & $\begin{array}{c}90^{\mathrm{a}} \\
(0.79-1.01)\end{array}$ & $\begin{array}{c}21.97^{\mathrm{a}} \\
(12.19-31.74)\end{array}$ & $\begin{array}{c}90^{\mathrm{a}} \\
(0.79-1.01)\end{array}$ & $\begin{array}{c}22.66^{\mathrm{a}} \\
(19.01-26.33)\end{array}$ \\
\hline $25<\mathrm{TL} \leq 30$ & 30 & $\begin{array}{c}43.33^{\mathrm{b}} \\
(0.25-0.62)\end{array}$ & $\begin{array}{c}11.10^{\mathrm{a}} \\
(1.87-20.33)\end{array}$ & $\begin{array}{c}63.33^{\mathrm{b}} \\
(0.45-0.82)\end{array}$ & $\begin{array}{c}13.66^{\mathrm{b}} \\
(9.12-18.21)\end{array}$ \\
\hline $30<\mathrm{TL}$ & 30 & $\begin{array}{c}63.33^{b} \\
(0.45-0.82)\end{array}$ & $\begin{array}{c}14.53^{\mathrm{b}} \\
(4.52-24.54)\end{array}$ & $\begin{array}{c}56.66^{\mathrm{b}} \\
(0.38-0.75)\end{array}$ & $\begin{array}{c}11.66^{\mathrm{b}} \\
(7.27-16.06)\end{array}$ \\
\hline
\end{tabular}


found between spring and winter (PN: $\chi^{2}=8.533, \mathrm{p}=$ 0.003; AN: $\chi^{2}=11.305, \mathrm{p}=0.010$ ) and spring and summer (PN: $\chi^{2}=10.157, \mathrm{p}=0.001$; $\mathrm{AN}: \chi^{2}=11.419, \mathrm{p}=$ $0.010)$. Nodules were also found in fish collected in the spring of 2009, with a PN of $100 \%$, and a nonsignificant trend was observed between the $2 \mathrm{yr}$ (Table 3). PN and AN were also significantly higher in the smaller Trachyrincus scabrus than in larger individuals $\left(\chi^{2}=8.889, \mathrm{p}=0.012\right.$ and $\chi^{2}=14.459, \mathrm{p}=$ 0.025 , respectively) (Table 4). No significant difference relating $\mathrm{AB}$ and $\mathrm{AN}$ among the seasons and the host size were found. The abundance of Bathycreadium elongatum seems to be related to the 4 categories of abundance of nodules $\left(F_{3.79}=4.572, \mathrm{p}=0.005\right)$.

Encysted larval nematodes were often observed close to the apical zones of the pyloric caeca. These nematodes were probably larvae of Hysterothylacium sp., as it was the only encysted nematode species observed in the macroscopical examinations (interlabia well developed, both ventricular appendix and intestinal caecum present, and primordial gonads). When nodules with digeneans and nematode parasites were found in close proximity, nematodes were also surrounded by the inflammatory reaction of the nodules.

\section{DISCUSSION}

Adult digeneans in fish are primarily parasites of the digestive tract (Paperna \& Dzikowski 2006). However, some digenean families have become specialised for extraintestinal habitats, such as didymozoids within host tissues (Mladineo 2006) or aporocotylids in blood vessels (Paperna \& Dzikowski 2006). Digeneans found in the visceral cavity are usually larval forms, such as metacercariae, waiting for the following host in their life cycles (Paperna \& Dzikowski 2006), but some adult digeneans can also be found in the abdominal cavity as part of their life cycle. The metacercariae of Aphalloides coelomicola migrate to the visceral cavity of the common goby Pomatoschistus microps to become an adult (Maillard 1973, Pampoulie et al. 2000). In this case neither adults nor eggs are degraded in the visceral cavity and A. coelomicola can complete its cycle when the fish dies (Pampoulie et al. 2000). The bucephalid Paurorhynchus hiodontis normally lives in the gut of the mooneye Hiodon tergisus, but it can also be present in the body cavity (Manter 1957).

Bathycreadium elongatum has been described in marine gadiform fishes in the Mediterranean Sea (Cribb 2005), but this is the first report of this species in the digestive tract of Trachyrincus scabrus. Furthermore, a new but apparently accidental location of this parasite in the body cavity is described, since molecular results prove that both intracaecal $B$. elongatum and the nodule cores belong to the same species. We can confirm that the presence of $B$. elongatum in the visceral cavity is not artifactual or post mortem, since there was a host response around the digenean. Parasite presence out of the gut can be explained by a passive displacement of $B$. elongatum when the apical zone of $T$. scabrus pyloric caeca is ruptured. This presence is a consequence of an accidental and unspecific mechanism, since it would not be integrated into the life cycle of the parasite, and partially removes $B$. elongatum from fish intestine. Other parasites that also live in the digestive tract of T. scabrus, such as nematodes or acanthocephalans, do not seem to be affected by this process owing to their anatomy and physiology, as they are longer and larger than digeneans and, in the case of acanthocephalans, their attachment to the intestinal mucosa is very effective. The occurrence of B. elongatum nodules may affect other parasites in mesentery, such as larval nematodes. Nematodes are usually encysted in the serosa of the intestine but without an apparent inflammatory reaction and only surrounded by a thin layer of serosal tissue (Smith \& Wootten 1978). However, in the present study, a general inflammatory reaction in the visceral cavity related to the presence of $B$. elongatum could affect these encysted nematodes, since they are living in an unexpectedly hostile surrounding. A similar inflammatory reaction is observed in the responses of organisms toward a foreign body, as occurs in European smelt Osmerus eperlanus, in which food-induced granulomas were described in the oral cavity surrounding cuticular fragments of dietary amphipods (Anders \& Möller 1987), or in other gadiforms such as Atlantic cod Gadus morhua (F. E. Montero pers. obs.).

The histopathological response by the host could be influenced by the level of infection of parasites and by the organ or tissue affected. This response, if it exists, can range from a limited benign encapsulation of the parasite by the host cells to acute and chronic inflammation and necrosis (Feist \& Longshaw 2008). Intestinal trematodes are considered to be parasites that do not cause any clinically evident disease, even when the number of parasites is high (Paperna \& Dzikowski 2006), but rather only small local necrosis and degeneration in the mucosal layer caused by its ventral sucker and erosion of the mucosa in the most severe cases (Erasmus 1972). Nevertheless, some extraintestinal parasites may 
present a higher detrimental effect for the host (Paperna \& Dzikowski 2006). Platyhelminth presence within intra-abdominal tissues normally results in a granulomatous response by the host, which may include encapsulation and melanisation, that surrounds the parasite in order to isolate and destroy it (Sharp et al. 1992, Torres et al. 2002), as occurs with Bathycreadium elongatum in the visceral cavity of Trachyrincus scabrus. Studies of the histopathology associated with digenean infection in fish are scarce and are mostly limited to freshwater hosts (Taylor \& Hall 1993, Taylor et al. 1994, Dezfuli et al. 1997). These studies are focused on the penetration and migration of digenean larval stages (Paperna \& Dzikowski 2006) or digenean endoparasites that naturally invade host tissues as a part of their life cycle (Ogawa et al. 1989, Mladineo 2006).

In the present study the different observations throughout the seasons seem to indicate the presence of a process of passive release and degradation of parasites within the visceral cavity. In marine habitats, active shedding of cercariae and infection of fish commonly take place during the warmer times of the year (Matthews 1973, Køie 1975, Cottrell 1977). In our study, 1 metacercaria was found in the stomach in winter and 5 in early spring (cold seasons in shallow waters), which suggests that in Trachyrincus scabrus the transmission takes place in these seasons. Furthermore, digeneans in the pyloric caeca and intestine were predominantly juveniles during these seasons whereas in autumn adults were predominant. This apparent seasonality of the development of the parasite in the host does not correspond with the constant nature of hydrographic factors, such as temperature and salinity (about $13^{\circ} \mathrm{C}$ and 38.4 , respectively) of deeper waters in the Mediterranean Sea from $200 \mathrm{~m}$ downwards (Salat \& Cruzado 1981). T. scabrus tends to live close to the bottom unlike other macrourid species (Massutí et al. 1995, Carrassón \& Matallanas 2002). Therefore, seasonality in the life cycle of this parasite could be associated with a higher abundance of the intermediary hosts such as crustaceans. Crustaceans in deep-sea regions off the Catalonian coast (NW Mediterranean) show greatest abundance in winter and spring (Mamouridis et al. 2011), which coincides with the findings of metacercariae in T. scabrus. Spring is the season with the greatest abundance of Bathycreadium elongatum within pyloric caeca and nodules in the mesentery of $T$. scabrus. This fact supports the belief that spring is the season of the highest recruitment of parasites in pyloric caeca. During summer, although the abundance of $B$. elongatum decreases, its prevalence remains quite high; therefore, parasite recruitment and maturation apparently continue. At this time, in spring and during summer, when several parasites are inside the pyloric caeca, more parasites would be displaced to the visceral cavity, apparently through the pyloric caecum apex owing to the fragility of this zone. For this reason, parasites surrounded by intestinal mucosa were observed within the mesentery during both seasons. In the mesentery parasites become degraded through a granulomatous inflammatory response, macroscopically observed as nodules that show a more advanced degradation of their content in autumn. This could be one of the causes for the drastic decline of the population of $B$. elongatum in autumn. Adult and juvenile parasite levels rise again in winter, reaching their maximum in spring, and this new increase could be associated with the next infection wave by new metacercariae. This seems to be an anomalous process for the parasite since not only are the adults trapped and degraded in the connective tissue, but so are their eggs, and thus the parasites have no possibility of completing their life cycle.

In conclusion, Bathycreadium elongatum infects Trachyrincus scabrus in high prevalence and abundance. However, this infection may be greatly affected by an unusual and particular process of passive release of these parasites from the pyloric caeca to the abdominal cavity, thereby removing a substantial load of potentially viable parasites and eggs from the life cycle. This process apparently reduces the efficiency of the life cycle of this parasite in T. scabrus, since it could be acting as a partial 'cul de sac' for $B$. elongatum in its environment where other hosts exist.

Acknowledgements. This study was supported by Spanish Science and Technology Ministry project BIOMARE (CTM2006-13508-C02-01MAR), Complementary Action (CTM 2006-28145-E/MAR) and ANTROMARE (CTM200912214-C02-02). M. Constenla has a PIF PhD student grant from the Universitat Autònoma de Barcelona. C.M.M. has a FPU grant from the Ministerio de Educación y Ciencia. We are grateful to Dr. A. Kostadinova for critically reading the manuscript. We also thank C. Simmons for the English revision of this manuscript.

\section{LITERATURE CITED}

Anders K, Möller H (1987) Food-induced granulomatosis in European smelt, Osmerus eperlanus. Can J Fish Aquat Sci 44:1848-1854

Bowles J, Hope M, Tiu WU, Liu X, McManus DP (1993) Nuclear and mitochondrial genetic markers highly conserved between Chinese and Philippine Schistosoma japonicum. Acta Trop 55:217-229

Bray RA (1973) Some digenetic trematodes in fishes from the 
Bay of Biscay and nearby waters. Bull Br Mus (Nat Hist) Zool 26:149-183

Bray RA (1995) Annotated checklist of digenean parasites of Macrouridae (Teleostei, Gadiformes). Acta Parasitol 40: 168-192

Bray RA (2004) The bathymetric distribution of the digenean parasites of deep-sea fishes. Folia Parasitol 51:268-274

- Bush AO, Lafferty KD, Lotz JM, Shostak AW (1997) Parasitology meets ecology on its own terms: Margolis et al. revisited. J Parasitol 83:575-583.

Carrassón M, Matallanas J (2002) Diets of deep-sea macrourid fishes in the western Mediterranean. Mar Ecol Prog Ser 234:215-228

Chambers CB, Carlisle MS, Dove ADM, Cribb TH (2001) A description of Lecithocladium invasor n.sp. (Digenea: Hemiuridae) and the pathology associated with two species of Hemiuridae in acanthurid fish. Parasitol Res 87: 666-673

Cottrell B (1977) The immune response of plaice (Pleuronectes platessa L.) to the metacercariae of Cryptocotyle lingua and Rhipidocotyle johnstonei. Parasitology 74:93-107

Cribb TH (2005) Family Opecoelidae Ozaki, 1925. In: Jones A, Bray RA, Gibson DI (eds) Keys of the Trematoda, Vol 2. The Natural History Museum, London, p 443-532

Cribb TH, Anderson GR, Adlard RD, Bray RA (1998) A DNA-based demonstration of a three-host life-cycle for the Bivesiculidae (Platyhelminthes: Digenea). Int J Parasitol 28:1791-1795

> Dezfuli BS, Manera M, Onestini S, Rossi R (1997) Histopathology of the alimentary canal of Anguilla anguilla L. associated with digenetic trematodes: a light and electron microscopic study. J Fish Dis 20:317-322

Erasmus DA (1972) The biology of trematodes. The University Press, Belfast

- Feist SW, Longshaw M (2008) Histopathology of fish parasite infections -importance for populations. J Fish Biol 73:2143-2160

Jousson O, Bartoli P, Pawlowski J (1999) Molecular identification of developmental stages in Opecoelidae (Digenea). Int J Parasitol 29:1853-1858

Klimpel S, Seehagen A, Palm HW, Rosenthal H (2001) Deepwater metazoan fish parasites of the world. Logos, Berlin

Klimpel S, Palm HW, Busch MW, Kellermanns E, Rückert S (2006) Fish parasites in the Arctic deep-sea: poor diversity in pelagic fish species vs. heavy parasite load in a demersal fish. Deep-Sea Res I 53:1167-1181

Klimpel S, Busch MW, Kellermanns E, Kleinertz S, Palm HW (2009) Metazoan deep-sea fish parasites. Acta Biol Benrodis Suppl 11, Verlag Natur \& Wissenschaft, Solingen

Køie M (1975) On the morphology and life-history of Opechona bacillaris (Molin, 1859) Looss, 1907 (Trematoda, Lepocreadiidae). Ophelia 13:63-86

Littlewood DTJ, Curini-Galletti M, Herniou EA (2000) The interrelationships of Proseriata (Platyhelminthes: Seriata) tested with molecules and morphology. Mol Phylogenet Evol 16:449-466

Maillard C (1970) Nicolla elongata n. sp. (Digenea, Coitocaecidae), parasites d'Onos tricirratus (Brünnich, 1768) (Teleostei). Bull Mus Natl Hist Nat Ser 2 42:410-414

Maillard C (1973) Mise en évidence du cycle évolutif abrégé d'Aphalloïdes coelomicola Dollfus, Chabaud et Golvan, 1957 (Trematoda). Notion d'hôte historique. CR Acad Sci Série D, Paris, p 277-317

Mamouridis V, Cartes JE, Parra S, Fanelli E, Saiz Salinas JI
(2011) A temporal analysis on the dynamics of deep-sea macrofauna: influence of environmental variability off Catalonia coasts (western Mediterranean). Deep-Sea Res I 58:323-337

Manter HW (1957) Host specificity and other host relationships among the digenetic trematodes of marine fishes. In: Baer JG (ed) Premier Symposium sur la spécifité parasitaire des parasites des vertèbres. Institut de Zoologie, Université de Neuchâtel, Neuchâtel 185-197

> Massutí E, Morales B, Stefanescu C (1995) Distribution and biology of five grenadier fish (Pisces: Macrouridae) from the upper and middle slope of the northwestern Mediterranean. Deep-Sea Res I 42:307-330

Matthews RA (1973) The life-cycle of Bucephalus haimanus Lacaze-Duthiers 1845 from Cardium edule, L. Parasitology 67:341-350

> Mladineo I (2006) Histopathology of five species of Dydimocystis spp. (Digenea: Didymozoidae) in cage-reared Atlantic bluefin tuna (Thunnus thynnus thynnus). Vet Res Commun 30:475-484

Nasira K, Bilqees FM, Sadia H, Khatoon N, Huma S (1998) Histopathological changes caused by trematode Stomachicola muraenesocis (Yamaguti 1934) in the stomach of fish Muraenesox cinereus (Forsk 1775). Proc Pak Congr Zool 18:181-186

Ogawa K, Hattori K, Hatai K, Kubota S (1989) Histopathology of cultured marine fish, Seriola purpurascens (Carangidae) infected with Paradeontacylis spp. (Trematoda: Sanguinicolidae) in the vascular system. Fish Pathol 24:75-81

Palm HW, Klimpel S (2008) Metazoan fish parasites of Macrourus berglax Lacepède, 1801 and other macrourids of the North Atlantic: invasion of the deep sea from the continental shelf. Deep-Sea Res II 55:236-242

Pampoulie C, Lambert A, Rosecchi E, Crivelli AJ, Bouchereau JL, Morand S (2000) Host death: a necessary condition for the transmission of Aphalloides coelomicola Dollfus, Chabaud and Golvan, 1957 (Digenea, Cryptogonimidae)? J Parasitol 86:416-417

Paperna I, Dzikowski R (2006) Digenea (phylum Platyhelminthes). In: Woo PTK (ed) Fish diseases and disorders, Vol 1: protozoan and metazoan infections. CAB International, Wallingford, p 345-390

Salat J, Cruzado A (1981) Masses d'eau dans la Méditerranée occidentale: Mer Catalane et eaux adjacentes. Rapp P-V Réun Comm Int Explor Sci Mer Méditerr 27:201-209

Sharp GJE, Pike AW, Secombes CJ (1992) Sequential development of the immune response in rainbow trout [Oncorhynchus mykiss (Walbaum, 1792)] to experimental plerocercoid infections of Diphyllobothrium dendriticum (Nitzsch, 1824). Parasitology 104:169-178

Smith JW, Wootten R (1978) Anisakis and anisakiasis. Adv Parasitol 16:93-163

- Taylor LH, Hall BK (1993) Experimental infection of yellow perch (Perca flavescens) with Apophallus brevis (Digenea, Heterophyidae): parasite invasion, encystment, and ossicle development. Can J Zool 71:1886-1894

Taylor LH, Hall BK, Miyake T, Cone DK (1994) Ectopic ossicles associated with metacercariae of Apophallus brevis (Trematoda) in yellow perch, Perca flavescens (Teleostei): development and identification of bone and chondroid bone. Anat Embryol 190:29-46

Torres P, Lopez JC, Cubillos V, Lobos C, Silva R (2002) Visceral diphyllobothriosis in a cultured rainbow trout, Oncorhynchus mykiss (Walbaum), in Chile. J Fish Dis 25: 375-379

Submitted: January 26, 2011; Accepted: July 4, 2011

Proofs received from author(s): September 8, 2011 